The Canadian Mineralogist

Vol. 39, pp. 557-571 (2001)

\title{
PARENTAL MAGMA AND EMPLACEMENT OF THE STRATIFORM UITKOMST COMPLEX, SOUTH AFRICA
}

\author{
SYBRAND A. DE WAAL ${ }^{\S}$ AND WOLFGANG D. MAIER \\ Department of Geology, University of Pretoria, Pretoria 0002, Republic of South Africa \\ RICHARD A. ARMSTRONG \\ Research School of Earth Sciences, The Australian National University, Canberra, ACT 0200, Australia \\ CHRISTOPH D.K. GAUERT ${ }^{\mathbb{I I}}$ \\ Department of Geology, University of Pretoria, Pretoria 0002, Republic of South Africa
}

\begin{abstract}
The Uitkomst Complex, a Ni-Cu-PGE-Cr-mineralized layered basic intrusion situated approximately $200 \mathrm{~km}$ due east of Pretoria, South Africa, hosts commercially viable magmatic base-metal sulfide deposits. The Complex has a concordant ${ }^{207} \mathrm{~Pb} /{ }^{206} \mathrm{~Pb}$ zircon age of $2044 \pm 8 \mathrm{Ma}$, suggesting that it is coeval with the Rustenburg Layered Suite (RLS) of the Bushveld Complex. Chemical modeling, using summation and least-squares optimization techniques, provides evidence that the boninitic Bushveld B1 magma is parental to both the lower ultrabasic and upper basic layered series of the Uitkomst Complex. The layered series crystallized in two stages, i.e., a lower conduit and an upper closed-system stage. The tubular shape of the Uitkomst Complex is the result of the intersection of a near-horizontal bedding plane fault with an existing vertical fracture zone under tensional conditions. During the conduit stage, a combination of magma mixing, contamination and flow dynamics may have facilitated sulfide formation and segregation. The identification of Bushveld B1 magma as the major parental magma of the Uitkomst Complex has significance in the exploration for similarly mineralized sub-RLS intrusive bodies.
\end{abstract}

Keywords: layered basic intrusion, Uitkomst Complex, Ni-Cu-PGE-Cr mineralization, magma mixing, sulfide segregation, South Africa.

\section{SOMMAIRE}

Le complexe d'Uitkomst, situé environ $200 \mathrm{~km}$ à l'est de Pretoria, en Afrique du Sud, est un massif intrusif stratiforme minéralisé en Ni-Cu-PGE-Cr contenant des gîtes minéraux de métaux de base commercialement exploitables. Sa mise en place a eu lieu il y a $2044 \pm 8 \mathrm{Ma}$ (âge ${ }^{207} \mathrm{~Pb} /{ }^{206} \mathrm{~Pb}$ concordant déterminé sur zircon), et serait ainsi contemporaine de la série stratiforme de Rustenburg du complexe de Bushveld. D'après un modèle de son évolution chimique, fondé sur les bilans et une optimisation par moindres carrés, le magma parental B1 à Bushveld, d'aspect boninitique, aurait produit la série inférieure (ultrabasique) et la série supérieure (basique) du complexe d'Uitkomst. La séquence stratiforme aurait cristallisé en deux étapes, la partie inférieure dans un conduit et la partie supérieure en système fermé. L'aspect tubulaire du complexe d'Uitkomst résulterait d'une intersection d'un plan de litage sédimentaire presque horizontal avec une zone de fracture verticale sous régime d'extension. Au stade de développement du conduit, une combinaison de mélange de magmas, de contamination et d'épanchement dynamique pourrait avoir facilité la formation et la ségrégation des sulfures. La présence de la composante magmatique B1 du complexe de Bushveld comme magma parental prédominant dans le complexe d'Uitkomst aurait des implications dans les programmes d'exploration pour des massifs intrusifs semblablement minéralisés sous la séquence stratifiée de Rustenburg.

(Traduit par la Rédaction)

Mots-clés: massif intrusif basique stratiforme, complexe de Uitkomst, minéralisation en Ni-Cu-PGE-Cr, mélange de magmas, ségrégation de sulfures, Afrique du Sud.

§ E-mail address: sadw@ scientia.up.ac.za

II Present address: Institut für Geologische Wissenschaften, Martin-Luther-Universität, Domstr. 5, D-06120 Halle/Saale, Germany. 


\section{INTRODUCTION}

The Uitkomst Complex (Fig. 1), situated approximately $200 \mathrm{~km}$ east of Pretoria, is a layered basic intru-

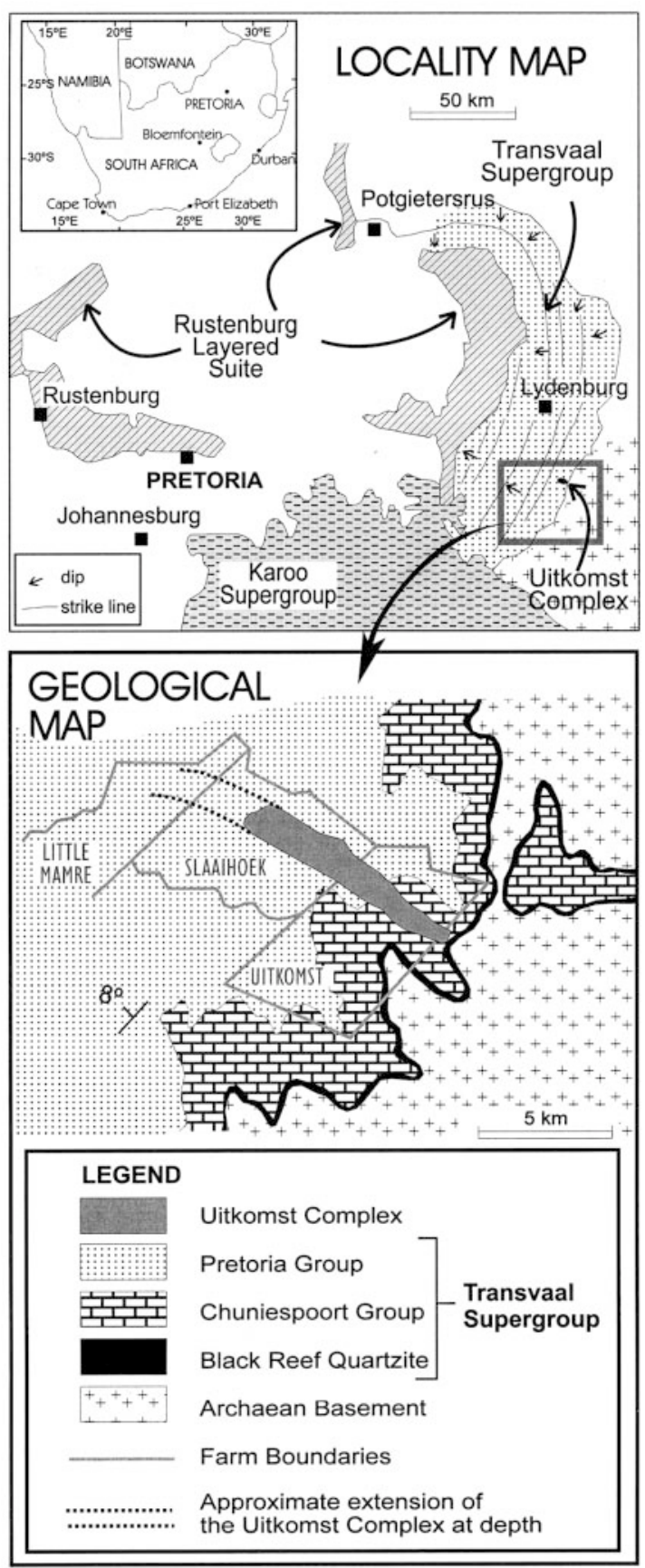

FIG. 1. Locality and simplified geological map of the Uitkomst Complex. sion emplaced in the Transvaal Supergroup. It consists of six major lithological units; from bottom to top, these are the Basal Gabbro, Lower Harzburgite, Chromitiferous Harzburgite, Main Harzburgite, Pyroxenite, and Gabbronorite units (Fig. 2) (Gauert et al. 1995, 1996, De Waal \& Gauert 1997). The body was first described by Wagner (1929), but only recently attracted major attention with the discovery of several lenses of massive sulfide ore (2.9 Mt at $2.04 \% \mathrm{Ni}, 1.13 \% \mathrm{Cu}$ and 6.17 $\mathrm{g} / \mathrm{t}$ combined PGE and Au) in its footwall (Anon. 1997). The massive sulfide lenses have been mined since 1996, and represent South Africa's only operating mine in which nickel is the main ore. In addition, three distinct disseminated zones (totalling $98 \mathrm{Mt}$ at $0.56 \% \mathrm{Ni}, 0.22 \%$ $\mathrm{Cu}$ and $1.1 \mathrm{~g} / \mathrm{t} \mathrm{PGE}$ and $\mathrm{Au}$ ) are present in lower three units of the Complex. Plans to mine the latter by openpit methods are being developed.

The elongate, tubular shape of the body, having an inferred aspect ratio of more than 12 to 1 , as well as lithological and geochemical characteristics, led Gauert et al. (1995) to propose that the Complex crystallized in two stages. Accordingly, the bulk of the harzburgitic units is inferred to have crystallized under open-system conditions from a magma that flowed through a conduit-like chamber (the "conduit stage"), whereas the upper portions of the Complex seem to have crystallized in a closed system as a result of an apparent de-activation of the conduit (the "closed-system stage"). This hypothesis has, until now, not been tested independently.

In this paper, we present the first conclusive evidence that the Uitkomst Complex is coeval with the Bushveld Complex, and that the bulk of the cumulates of the layered series are the products of crystallization of a magma similar in composition to the boninitic B1 parental magma of the Bushveld Complex (Sharpe 1981, Harmer \& Sharpe 1985, Davies \& Tredoux 1985, Hatton \& Sharpe 1989). We use the term "boninitic" purely in a chemical-descriptive sense, without any genetic implications. Combined with results of earlier studies on the chilled zone of the Basal Gabbro Unit (De Waal \& Gauert 1997, De Waal and Armstrong, 2000), the parental magmas of the entire sequence of rocks in the Complex can now be accounted for. These findings provide a solid basis on which to study the nature and genesis of the concentrations of massive and disseminated sulfide present in the Uitkomst Complex.

$$
\begin{aligned}
& \text { Review of the Geology } \\
& \text { OF THE UitKomst Complex }
\end{aligned}
$$

\section{Field relations}

The Uitkomst Complex outcrops on the farms Uitkomst 541JT and Slaaihoek 540JT over a total distance of $9 \mathrm{~km}$ (Fig. 1). From borehole information, it is known to extend to the northwest for at least another 3 $\mathrm{km}$, to the farm Little Mamre 538JT. In the latter local- 


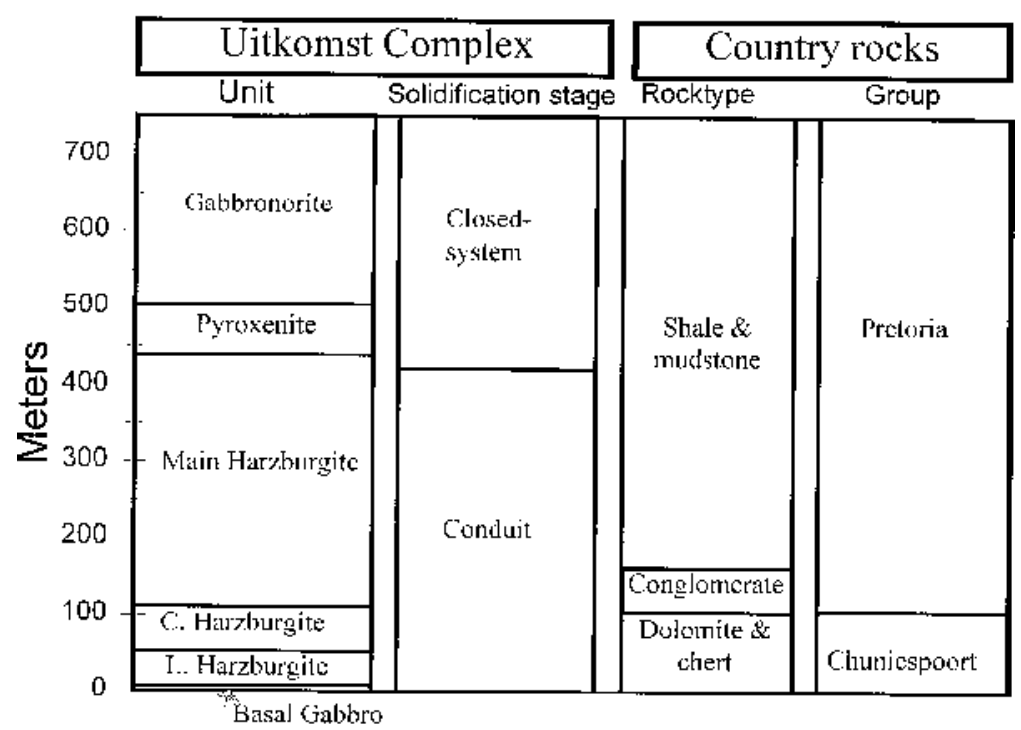

FIG. 2. Lithological subdivision, solidification stage and country rocks of the Uitkomst Complex, after Gauert et al. (1995). Thicknesses of units are averaged.

ity, the roof of the Complex is in contact with sedimentary rocks of the Pretoria Group of the Transvaal Supergroup.

The intrusive body plunges at about 4 to $8^{\circ}$ to the northwest, with its roof and floor contacts concordant to the bedding planes of the country rocks. The roof and floor contacts, the modal igneous layering, as well as the contacts between the different lithological units in the Complex, are essentially parallel to each other. The total thickness of the cumulate sequence, including the chilled zones, averages about $750 \mathrm{~m}$, but vertical dilation, due to numerous post-consolidation diabase sills, results in an effective thickness of about $850 \mathrm{~m}$.

The Uitkomst Complex is roughly anvil-shaped in cross-section. The two profiles provided in Figure 3 are based on field and borehole information and corrected for late emplacement of diabase sills. A relatively narrow keel, measuring about $800 \mathrm{~m}$ in width and about $120 \mathrm{~m}$ in depth, is confirmed by surface mapping and extensive drilling. Existing borehole information indicates that this keel is present over the entire known length of the body. Above the keel, the Complex flares out to a width of about $1200 \mathrm{~m}$, with the center of this wider section slightly offset to the southwest. Borehole data prove that this widening feature is also consistent in the direction of plunge. Another broadening up to $1600 \mathrm{~m}$ in cross-sectional width (Gauert 1998) occurs at a level some $500 \mathrm{~m}$ above the base of the Complex. Von Scheibler et al. (1995) mapped sill-like lateral extensions of the Gabbronorite Unit at a level of approximately $550 \mathrm{~m}$ above the base of the body. Owing to poor outcrop, the total width of these extensions is unknown. From the limited field and borehole information, the roof of the body seems to be flat and to have a width of approximately $1600 \mathrm{~m}$.

\section{Lithology}

The base of the Complex is formed of the Basal Gabbro Unit, which ranges between zero and $12 \mathrm{~m}$ (average $6 \mathrm{~m}$ ) in thickness. It has a well-defined aphanitic chilled zone ranging between 0.1 and $1.8 \mathrm{~m}$ in thickness, and is in contact with the quartzitic rocks of the Oaktree Formation, Chuniespoort Group (Fig. 2). The remainder of the Unit is a relatively homogeneous, poorly layered, medium-grained gabbro consisting largely of plagioclase ( $\mathrm{An}_{59}$ to $\mathrm{An}_{29}$; up to 50 modal \%), clinopyroxene $\left(\mathrm{En}_{41} \mathrm{Fs}_{25} \mathrm{Wo}_{35} ; 20-30\right.$ modal \%) and orthopyroxene $\left(\mathrm{En}_{65} \mathrm{Fs}_{31} \mathrm{Wo}_{4}\right.$ to $\mathrm{En}_{62} \mathrm{Fs}_{34} \mathrm{Wo}_{4} ; 10$ modal $\%)$. Minor amounts of olivine may occur toward the upper part of the Unit, where it generally forms anhedral equigranular crystals less than $0.2 \mathrm{~mm}$ in size that are poikilitically enclosed in orthopyroxene and plagioclase oikocrysts. Apart from secondary alteration minerals, accessory phases include titanian magnetite, quartz and sulfides (pyrrhotite, chalcopyrite, pentlandite, and subordinate pyrite and arsenopyrite).

The Lower Harzburgite Unit is approximately $50 \mathrm{~m}$ thick and contains a variety of ultramafic rock types, including harzburgite, websterite, wehrlite, and peridotite. It has a transitional relationship with the underlying Basal Gabbro Unit. The main phases are olivine (cumu- 

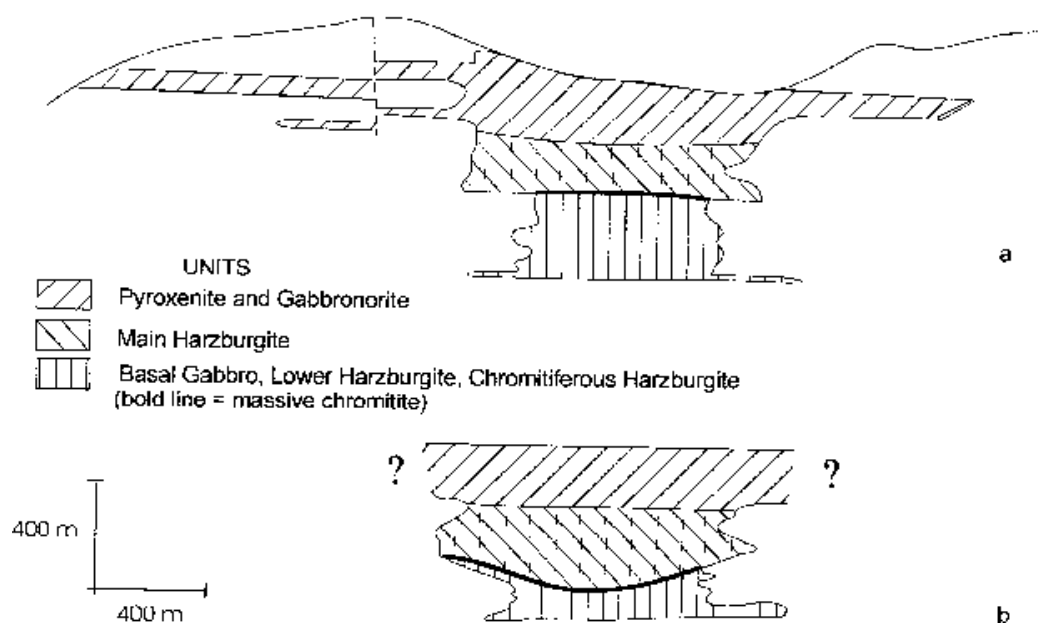

FIG. 3. Schematic cross-sections of the Uitkomst Complex. (a) Von Scheibler et al. (1995) based their "idealized cross-section" on information derived from boreholes and mapping. (b) De Waal \& Gauert (1997) used borehole information from the Slaaihoek Little Mamre boundary to construct their cross-section, illustrating the synformal nature of the massive chromitite at the top of the Chromitiferous Harzburgite Unit, as well as a flat roof contact.

lus, $\sim \mathrm{Fo}_{79}$; up to 50 modal \%), orthopyroxene (intercumulus, $\mathrm{En}_{84} \mathrm{Fs}_{13} \mathrm{Wo}_{3}$ to $\mathrm{En}_{82} \mathrm{Fs}_{14} \mathrm{Wo}_{4}$; up to 30 modal \%), clinopyroxene (intercumulus, $\mathrm{En}_{43} \mathrm{Fs}_{10} \mathrm{Wo}_{49}$ to $\mathrm{En}_{38} \mathrm{Fs}_{11} \mathrm{Wo}_{52}$; up to 40 modal \%), chromian spinel (chemically variable, average $\mathrm{Mg} /(\mathrm{Mg}+\mathrm{Fe}) \approx 0.5, \mathrm{Cr} /$ $(\mathrm{Cr}+\mathrm{Fe}+\mathrm{Al}) \approx 0.55$; up to 10 modal $\%)$, and plagioclase (intercumulus, $\mathrm{An}_{67}$ to $\mathrm{An}_{43}$; up to 10 modal \%). The unit contains numerous xenoliths of dolostone. Of particular interest are the clinopyroxene-bearing rocks, which appear to occur in specific correlatable horizons. They commonly are associated with dolostone xenoliths and contain elevated amounts of net-textured sulfides $(10-25 \%)$. The sulfide assemblage is dominated by pyrrhotite, pentlandite and chalcopyrite, but contains also minor pyrite, millerite, cobaltite and violarite (van Zyl 1996).

The Lower Harzburgite Unit grades into olivine chromian spinel cumulate of the Chromitiferous Harzburgite Unit (average thickness: $60 \mathrm{~m}$ ). Olivine and chromian spinel (composition similar to that of the Lower Harzburgite) are the predominant cumulus phases in this unit. Orthopyroxene is the main intercumulus phase, poikilitically enclosing olivine and chromian spinel. Chromian spinel forms numerous schlieren and layers that increase in abundance with height until a massive chromitite of between 3 and $14 \mathrm{~m}$ in thickness defines the top of the Unit. Sulfides consti- tute 1 to $5 \%$ of the rock, with clinopyroxene-bearing lithologies being particularly enriched.

The overlying Main Harzburgite Unit (average thickness: $330 \mathrm{~m}$ ) is an olivine - chromian spinel - orthopyroxene rock with weakly developed meter-scale phase and grain-size layering. Olivine $\left(\mathrm{Fo}_{89}\right.$ to $\left.\mathrm{Fo}_{86}\right)$ and chromian spinel are contained in oikocrysts of mainly orthopyroxene $\left(\mathrm{En}_{88} \mathrm{Fs}_{10} \mathrm{Wo}_{3}\right.$ to $\left.\mathrm{En}_{84} \mathrm{Fs}_{12} \mathrm{Wo}_{3}\right)$, and lesser plagioclase $\left(\mathrm{An}_{81}\right.$ to $\left.\mathrm{An}_{43}\right)$ and clinopyroxene $\left(\sim \mathrm{En}_{43} \mathrm{Fs}_{8} \mathrm{Wo}_{49}\right)$. The chromian spinel in the Main Harzburgite becomes more Fe-rich near the top of the unit, with $\mathrm{Mg} /(\mathrm{Mg}+\mathrm{Fe}) \approx 0.4$ and $\mathrm{Cr} /(\mathrm{Cr}+\mathrm{Fe}+\mathrm{Al}) \approx$ 0.5 (Gauert et al. 1995). Several pyroxenitic and dunitic layers occur throughout the unit. Although localized concentrations of sulfides (pyrrhotite, pentlandite, chalcopyrite with traces of mackinawite and cubanite; Van Zyl 1996) of up to $5 \%$ may occur, this unit is much poorer in sulfides than the underlying ultramafic units.

Overlying the Main Harzburgite Unit is a transitional sequence of some $60 \mathrm{~m}$ in thickness referred to as the Pyroxenite Unit (Gauert 1998). Its base is defined by a marked increase in $\mathrm{SiO}_{2}$ and a simultaneous increase in modal and normative orthopyroxene $\left(\sim \mathrm{En}_{87} \mathrm{Fs}_{10} \mathrm{Wo}_{3}\right)$. In contrast, the concentration of plagioclase (intercumulus, $\sim \mathrm{An}_{61}$ ) remains initially unchanged, but increases progressively mid-way through the unit. Chromian spinel (cumulus, $\mathrm{Mg} /(\mathrm{Mg}+\mathrm{Fe}) \approx 0.4$ and $\mathrm{Cr}$ 
$/(\mathrm{Cr}+\mathrm{Fe}+\mathrm{Al}) \approx 0.5)$ and clinopyroxene (intercumulus, $\sim \mathrm{En}_{43} \mathrm{Fs}_{7} \mathrm{Wo}_{50}$ ) are subordinate.

The base of the overlying Gabbronorite Unit has been set by Gauert (1998) to occur where the amount of plagioclase exceeds 50 modal \%. In these rocks, the An content of the cumulus plagioclase reaches up to 85 to $90 \%$. The concentration of sulfides rarely exceeds 1 modal \%. Accessory phases include chromian spinel and titanian magnetite.

The Gabbronorite Unit remains relatively poorly studied. The Unit is $250 \mathrm{~m}$ thick and ranges from a basal norite (orthopyroxene - plagioclase cumulate), through gabbro to a diorite (plagioclase $\mathrm{An}_{<50}$, with small quantities of quartz) in its upper reaches. Euhedral grains of titanian magnetite form a common constituent throughout the Unit and may reach up to $15 \%$ in individual samples. A thin (10-20 cm) layer of magnetitite is commonly developed in the lower portion. Sulfides occur in amounts of less than $1 \%$. The Gabbronorite Unit displays a well-defined chilled zone against the roof rocks.

A fine-grained homogeneous gabbroic rock is also found between the northeastern sidewall of the intrusion and the layered rocks of the Main Harzburgite Unit (180 $\mathrm{m}$ above the base of the intrusion) on Uitkomst 541JT (De Waal \& Gauert 1997). This rock is referred to as the Marginal Gabbro and is chemically comparable to the Basal Gabbro Unit.

\section{Alteration}

The cumulate rocks of the Complex have been affected by a hydrothermal event that caused widespread serpentinization of olivine, uralitization of pyroxene and saussuritization of plagioclase. In addition, the Lower and Chromitiferous Harzburgite Units are characterized by intense talc-carbonate alteration, which terminates abruptly at the level of the massive chromitite layer capping the Chromitiferous Harzburgite Unit. Above this layer, the Main Harzburgite Unit is serpentinized without any prominent development of talc or carbonate. The fact that the lower three units of the Complex are enclosed in dolomitic country-rock, which could have been responsible for a relatively high $\mathrm{CO}_{2}$ pressure and the stabilization of carbonate and talc during hydrothermal alteration, may explain the distribution of these secondary minerals. The age of this hydrothermal event is not known at present.

\section{GEOCHEMISTRY}

Selected samples from the Main Harzburgite, Pyroxenite and Gabbronorite Units were crushed and analyzed with X-ray-fluorescence techniques using pressed-powder pellets for trace elements (concentrations expressed in ppm) and fused glass discs for major elements (concentrations expressed as weight \%) (Norrish \& Hutton 1969). The compositional data are available from the first author and from the Depository of Unpublished
I'ABLE 1, AVERAGE COMPOSTTIONS OF THE MNI LNTTS. UITKOMIST COMPLEX

\begin{tabular}{|c|c|c|c|c|c|c|}
\hline Urit & $\mathrm{BGAB}$ & LHZBG & PCR & MHZBG & PXT & $\mathrm{G} 3$ \\
\hline $\mathrm{SiO}_{2} \mathrm{~m}+\%$ & $4 T .8(6.6)$ & $37.5(75)$ & $276 .(8.7)$ & $38.9(3.5)$ & $51.7(3.6)$ & $5.4,4(4,5)$ \\
\hline $\mathrm{TiO}_{2}$ & $0,9(0.7)$ & $0.3(0.7)$ & $0.4\{0.5\}$ & $02(0.1)$ & 1.2 (0.1) & $1.5(5,1)$ \\
\hline $\mathrm{ALO}_{3}$ & $9.4(41)$ & 4.7(2.0) & $8.8(2.0)$ & $3.6(1.3)$ & $90(5.7)$ & $16.4(3.4)$ \\
\hline$F \varepsilon_{2} O_{3}$ & $15.6(4.7)$ & $22.9(9.5)$ & $15.4(3.2)$ & $110(1.5)$ & $102(2.0)$ & $9.6(4.2)$ \\
\hline $\mathrm{MnO}$ & $0.2(01)$ & $0.2(0.1)$ & $0.4(0.1)$ & $0.2(0.0)$ & $02000)$ & $0.1(0.1)$ \\
\hline $\mathrm{M}-\mathrm{sO}$ & $12.1(8.8)$ & $17.7(70)$ & 17.1 (3) & $32.6(3.8)$ & $20.1([0,4)$ & $4.6(3.3)$ \\
\hline $\mathrm{CuO}$ & $6.8(2.5)$ & $70(3.9)$ & $3.0(1.3)$ & $2.1(2.2)$ & $4.5(79)$ & $6.7\{2.5\}$ \\
\hline $\mathrm{Na}_{2} \mathrm{~L}$ & $1.9(1.4)$ & $9.4\{0.5\}$ & $0.5(0.5)$ & $0.3(0.1)$ & $1.206)$ & $3.0(1.4)$ \\
\hline$K_{0} 0$ & $1,1(0,7)$ & $0.5(0.5)$ & $0.7(0.5)$ & $0.3(0.3)$ & $0.4(03)$ & $1.6(2.3)$ \\
\hline $\mathrm{P}_{2} \mathrm{O}_{3}$ & $0.1(0.1)$ & $0.0\{0.0\}$ & $0.1(0.1)$ & $0.0(0.0)$ & $0.0(00)$ & 0.1 (0.1) \\
\hline $\mathrm{Cr}_{2} \mathrm{O}_{3}$ & $0.4(1.3)$ & $1.5(34)$ & $18(104)$ & $30(3.7)$ & $04(0.3)$ & $0.0(0.0)$ \\
\hline 960 & $0.4(0.3)$ & $1.0(0.7)$ & $07(0.4)$ & $0.3(0.1)$ & $0.1(0.1)$ & $0.0(b)$ \\
\hline 5 & $2.3(1.9)$ & $0.6(3.7)$ & $1 B(1,7)$ & $02(0.3)$ & $0.2(0.4)$ & $0.3(0,5)$ \\
\hline $\mathrm{V}_{2} \mathrm{O}_{3}$ & $0,0(00)$ & $0.0(0.0)$ & $0.0(00)$ & $00(0.0)$ & $0.0(0.0)$ & $0.0(00)$ \\
\hline $\mathrm{H}_{7} \mathrm{O}^{\circ}$ & 0.1 (0.1) & $0.1(0.1)$ & $0.0(0,0)$ & $0.2(0.2)$ & $0.1,0.1\}$ & $0.3(0.5)$ \\
\hline LOI & $32(1.5)$ & $59(4 . B)$ & $2.5(\mathrm{t} 1)$ & $7.3(35)$ & $1,0,1.3)$ & I_] (1.0) \\
\hline
\end{tabular}

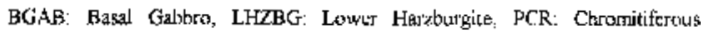
Harzhurgite, bIHZBG: Mair Harzbuf gite, PX: Pyroxenite, GN: Gabbronerite, icl Loss on igrition. The stetidetd dewiation is shown in parentheses.

Data, CISTI, National Research Council, Ottawa, Ontario K1A 0S2, Canada. Average compositions for the main lithological units are provided in Table 1.

\section{Age Dating}

$\mathrm{A}^{207} \mathrm{~Pb} /{ }^{206} \mathrm{~Pb}$ age determination was done on a borehole sample of diorite (sample SH181-SZ1) from the upper Gabbronorite Unit on the farm Slaaihoek, representing some of the last magma that crystallized in the Complex. Separates of clear zircon crystals from this sample were subjected to SHRIMP analysis at the facility of The Australian National University at Canberra, Australia. The weighted mean of the data yielded a concordant ${ }^{207} \mathrm{~Pb} /{ }^{206} \mathrm{~Pb}$ age of $2044 \pm 8 \mathrm{Ma}$ (Table 2, Fig. 4). This is nominally greater than the biotite age of $c a .2025$ Ma of Kenyon et al. (1986), and strongly suggests that the Uitkomst Complex is coeval with the overlying Bushveld Complex. Recent SHRIMP dating on zircon gives a ${ }^{207} \mathrm{~Pb} /{ }^{206} \mathrm{~Pb}$ age of $2054.5^{+1.6}{ }_{-1.1} \mathrm{Ma}$ (unpubl. data, R.A. Armstrong) for the Critical Zone of the Rustenburg Layered Suite of the Bushveld Complex.

\section{Estimation of the Parental Magma and Numerical Modeling}

\section{General}

Based on the new data reported above, it now seems that the Uitkomst Complex is coeval with the Bushveld Complex. Thus it is reasonable to assume that the magmas parental to the Bushveld Complex may also be parental to the Uitkomst Complex. Three main types of Bushveld Complex magmas have been proposed in the past (Sharpe 1985, Harmer \& Sharpe 1985): B1 is a 
TABLE 2. SUMMARY OF SHREMP UJPb ZIRCON RESIRTS FOR SAMPLE SHI8 I-SZ1, UTTKOMST COMPLEX

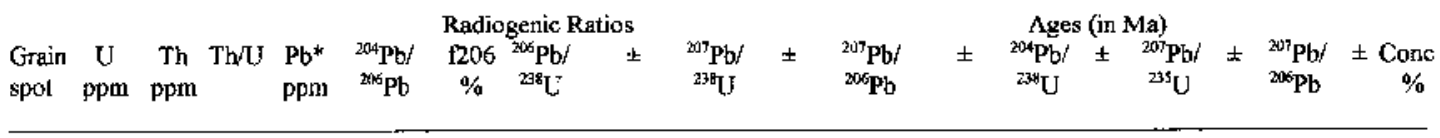

$\begin{array}{lllllllllllllll}1.1 & 294 & 113 & 0.39 & 113 & 0.00028 & 0.42 & 0.3632 & 0.0104 & 6.275 & 0.201 & 0.1253 & 0.0014 & 1997 & 49\end{array}$

$\begin{array}{llllllllllllllll}2.1 & 571 & 247 & 0.43 & 211 & 0.00006 & 0.10 & 0.3429 & 0.0095 & 5.938 & 0.175 & 0.1256 & 0.0009 & 1900 & 46\end{array}$

$\begin{array}{lllllllllllllll}3.1 & 585 & 308 & 0.53 & 229 & 0.00010 & 0.15 & 0.3579 & 0.0104 & 6.17 & 0.187 & 0.1250 & 0.0007 & 1972 & 49\end{array}$

$\begin{array}{llllllllllllllll}4.1 & 456 & 180 & 0.39 & 178 & 0.00008 & 0.12 & 0.3649 & 0.0116 & 6.357 & 0.214 & 0.1264 & 0.0010 & 2005 & 55\end{array}$

$\begin{array}{llllllllllllllll}5.1 & 565 & 262 & 0.46 & 219 & 0.00009 & 0.14 & 0.3595 & 0.0098 & 6.219 & 0.177 & 0.1255 & 0.0907 & 1980 & 47\end{array}$

$\begin{array}{llllllllllllllll}6.1 & 600 & 280 & 0.47 & 252 & 0.00006 & 0.09 & 0.3892 & 0.0110 & 6.803 & 0.202 & 0.1268 & 0.0008 & 2119 & 51\end{array}$

$\begin{array}{lllllllllllllllll}7.1 & 491 & 210 & 0.43 & 186 & 0.00013 & 0.19 & 0.3534 & 0.0098 & 6.069 & 0.178 & 0.1246 & 0.0008 & 1951 & 47\end{array}$

$\begin{array}{lllllllllllllll}8.1 & 397 & 188 & 0.47 & 155 & 0.00014 & 0.21 & 0.3593 & 0.0101 & 6.278 & 0.188 & 0.1267 & 0.0010 & 1979 & 48\end{array}$

$\begin{array}{lllllllllllllllll}9.1 & 484 & 213 & 0.44 & 194 & 0.00008 & 0.12 & 0.3721 & 0.0105 & 6.536 & 0.192 & 0.1274 & 0.0007 & 2039 & 49\end{array}$

$\begin{array}{lllllllllllllll}10.1 & 621 & 319 & 0.51 & 237 & 0.00008 & 0.12 & 0.3496 & 0.0098 & 5.995 & 0.181 & 0.1244 & 0.0010 & 1933 & 47\end{array}$

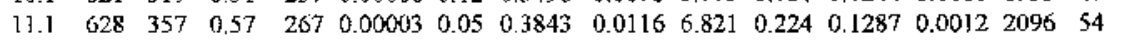

$\begin{array}{lllllllllllllll}12.1 & 373 & 182 & 0.49 & 153 & 0.00021 & 0.31 & 0.3735 & 0.0113 & 6.526 & 0.219 & 0.1267 & 0.0014 & 2046 & 53\end{array}$

$\begin{array}{lllllllllllllll}13.1 & 362 & 149 & 0.41 & 129 & 0.00020 & 0.30 & 0.3327 & 0.0094 & 5.804 & 0.178 & 0.1265 & 0.0011 & 1852 & 46\end{array}$

14.] $\quad \begin{array}{llllllllllllllllll}482 & 234 & 0.49 & 199 & 0.00014 & 0.21 & 0.3805 & 00106 & 6.648 & 0.198 & 0.1267 & 0.0009 & 2079 & 50\end{array}$

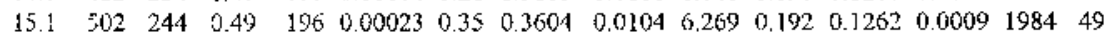

$\begin{array}{lllllllllllllll}16.1 & 610 & 276 & 0.46 & 238 & 0.00010 & 0.15 & 0.3603 & 0.0103 & 6.247 & 0.192 & 0.1258 & 0.0010 & 1083 & 49\end{array}$

$\begin{array}{rlllr}2015 & 29 & 2033 & 20 & 98 \\ 1967 & 26 & 2037 & 12 & 93 \\ 2000 & 27 & 2029 & 11 & 97 \\ 2026 & 30 & 2048 & 15 & 98 \\ 2007 & 25 & 2035 & 9 & 97 \\ 2086 & 27 & 2054 & 11 & 103 \\ 1986 & 26 & 2023 & 12 & 96 \\ 2015 & 27 & 2053 & 14 & 96 \\ 2051 & 26 & 2063 & 10 & 99 \\ 1975 & 27 & 2020 & 15 & 96 \\ 2089 & 29 & 2081 & 17 & 101 \\ 2049 & 30 & 2053 & 20 & 100 \\ 1947 & 27 & 2050 & 16 & 90 \\ 2066 & 27 & 2053 & 13 & 107 \\ 2014 & 27 & 2045 & 13 & 97 \\ 2011 & 27 & 2040 & 14 & 97\end{array}$

Notes: 1. Uncertainties given at the one sigma level. 2. f206\% denotes $\%$ of ${ }^{206} \mathrm{~Pb}$ that is common. 3. Correction for common $\mathrm{Pb}$ made using ${ }^{204} \mathrm{~Pb} / 206 / \mathrm{Pb}$ ratio. 4 . For Conc $\%, 100 \%$ denotes a concordant analysis.

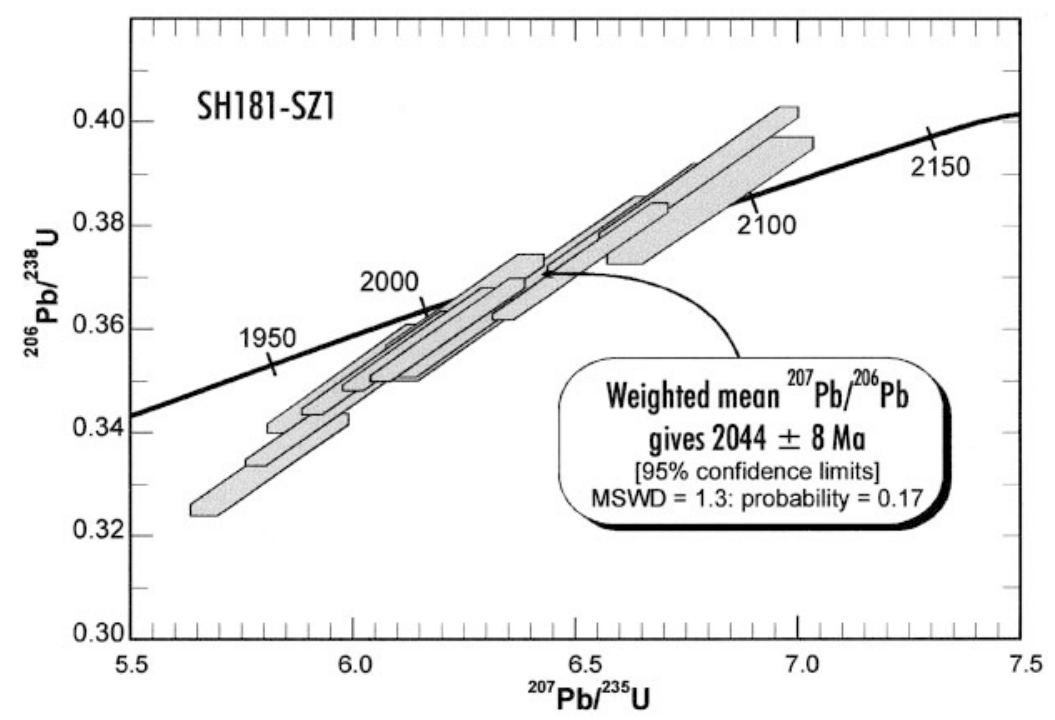

FIG. 4. Wetherill concordia diagram of SHRIMP data for sample SH181-SZ1. The Monte Carlo simulation and regression analysis, referred to in the text, is not shown. boninite ( $\left.c a .55 \% \mathrm{SiO}_{2}, 13 \% \mathrm{MgO}\right)$ and is considered parental to the Lower Zone of the Bushveld Complex. $\mathrm{B} 2$ and $\mathrm{B} 3$ are tholeiitic in composition $\left(\sim 50 \% \mathrm{SiO}_{2}\right.$, $\sim 7 \% \mathrm{MgO}$ ) and parental to the Critical and Main Zones of the Bushveld Complex.
The determination of the composition of magmas parental to cumulate rocks may be attempted in a number of ways. A widely used method has relied on the examination of the chilled marginal rocks of an intrusion, but these are commonly the most strongly contami- 
nated, such as at Muskox (Francis 1994) and Voisey's Bay (Li et al. 2000). De Waal \& Gauert (1997) and Strauss (1995) described the chilled contact rocks of the Basal Gabbro Unit as being essentially composed of $\mathrm{Na}$-Ti-enriched tholeiitic rocks. The degree to which these rocks are contaminated is at present not clearly resolved. For this reason and considering that the Basal Gabbro Unit is not per se part of the main layered sequence of the Uitkomst Complex, we have largely ignored this unit for the purpose of the present paper.

The composition of the parental magma can also be calculated from cumulus minerals, using suitable partition coefficients (Lambert \& Simmons 1987, Loferski et al. 1994, Mathez 1995), or from a putative trapped melt component (Bédard 1994). However, these methods have to correct for re-equilibration of the cumulus phases with trapped melt and zoning in some minerals, such as plagioclase and orthopyroxene.

Some investigators have attempted to calculate the bulk composition of intrusions (Morse 1969, Raedeke 1982). This approach requires a good knowledge of the shape of an intrusion and is based on the assumption that the system was closed. These conditions apply to the upper portion of the Uitkomst Complex; we therefore use a similar approach to that of Morse (1969) for this part of the intrusion.

\section{Closed-system stage}

The upper portion of the Uitkomst Complex shows a well-defined pattern of differentiation from ultramafic to dioritic rocks. This portion has a well-known geometry, i.e., the Main Harzburgite and the Pyroxenite Units have a reasonably constant average width of $1.2 \mathrm{~km}$, whereas the Gabbronorite Unit on average is about $1.6 \mathrm{~km}$ wide (Gauert 1998). For the initial approach, we ignored the lateral sill-like extensions postulated by Von Scheibler et al. (1995).

To determine which of the Bushveld magmas was parental to the closed-system stage, the cumulate sequence of the Uitkomst Complex is viewed as a series of $n$ discrete compositional increments, where $n$ refers to the number of samples taken over the sequence. The upper and lower boundaries of each given increment are defined by the halfway marks between the elevations of two successive samples. By adding the increment compositions, starting at the top of the cumulate pile and weighting each increment according to its relative width and thickness, the cumulative composition will move toward, and eventually reach, the composition of either B1, B2, or B3, whichever is parental to the closed-system stage of the Complex.

The main problem with such a calculation is that we must define the base of the closed system. Gauert (1998) suggested that the uppermost $50 \mathrm{~m}$ of the Main Harzburgite Unit should be regarded as the basal rocks of the closed system. However, this criterion was poorly constrained. Incorporation of too much ultramafic ma- terial from the underlying portion of the Complex (that has been interpreted as the conduit stage into the closed system) will shift the estimate of the parental magma toward excessively magnesian compositions. In contrast, placing the base of the closed system too high may yield compositions of parental magma that are too evolved. The method of calculation applied here allows us to determine the composition of the parental magma of the closed-system stage as well as the position of the base of the closed system.

The following formula was used:

$$
\begin{aligned}
& \text { 12.Hl.Cm(i)+16.Hu.Cm(i)= } \\
& \Sigma_{q=1}^{k} 12 \cdot h(q) \cdot C s(i, q)+\Sigma_{p=1}^{m} 16 \cdot h(p) \cdot C s(i, p)
\end{aligned}
$$

where the factor 12 is the width in hectometers $(\mathrm{km} \times$ 10) of the Main Harzburgite and the Pyroxenite units, 16 is the width in hectometers of the Gabbronorite Unit, $\mathrm{Hl}$ is the combined thickness of the Main Harzburgite and Pyroxenite units in the closed-system stage, $\mathrm{Hu}$ is the thickness of the Gabbronorite Unit, $C m(i)$ is the concentration of the $i^{\text {th }}$ oxide in the parental magma, $h(q)$ and $h(p)$ are the thickness of the $q^{\text {th }}$ and $p^{\text {th }}$ increments, respectively, and $C s(i, q)$ and $C s(i, p)$ are the concentrations of the $i^{\text {th }}$ element or oxide in the $q^{\text {th }}$ and $p^{\text {th }}$ increments, respectively. We use hectometers instead of kilometers simply to avoid unnecessary decimals.

Rearranging Equation (1) results in

$$
\begin{aligned}
& C m(i)=\left[\Sigma_{q=1}^{k} 12 \cdot h(q)+\Sigma_{p=1}^{m} 16 \cdot h(p) \cdot C s(i, p)\right] \\
& {[12 . H l .+16 . H u]^{-1}}
\end{aligned}
$$

which gives the composition of the parental liquid for the $i^{\text {th }}$ oxide or element in the closed system.

\section{Conduit stage}

The modeling of the parental magma of the conduit stage of the Complex is based on fresh borehole samples from the Main Harzburgite Unit over the interval between 116 and $370 \mathrm{~m}$ above base. Samples from the lower part of the conduit stage (between 6 and $116 \mathrm{~m}$ above base), which represent the Lower Harzburgite and Chromitiferous Harzburgite units, have been ignored in this study for two reasons. First, these rocks are enriched in chromian spinel or sulfide (or both). Correction procedures to allow comparisons with relatively sulfidepoor and chromian-spinel-poor cumulates are possible but difficult to control. Secondly, these rocks show advanced talc-carbonate alteration, which raises the possibility of element mobility.

We assume that in a conduit system, the composition of the rock is governed by the cumulus phases and trapped melt, with the latter representing almost unfractionated parental magma (i.e., the fraction of melt remaining in the crystallizing system approaches 1). Accordingly, the cumulates of the Main Harzburgite Unit (olivine and chromian spinel as cumulus crystals 
in a matrix composed mainly of intercumulus orthopyroxene, plagioclase, clinopyroxene and phlogopite) can be modeled as a ternary mixture of olivine, chromian spinel and magma. The model is illustrated in Figure 5. Also shown on this diagram is the line representing the $\mathrm{FeO}: \mathrm{MgO}$ ratio for a magma in equilibrium with the olivine $\left(\mathrm{Fo}_{88}\right)$ found in the conduit rocks, assuming that $K_{\mathrm{d}}^{\mathrm{O} / \mathrm{Magma}}(\mathrm{FeO} / \mathrm{MgO})=0.3$ (Roeder \& Emslie 1970). This line passes close to the composition of the B1 magma. Furthermore, we assume that compositional modification of the cumulus phases due to reaction with trapped melt would be negligible because the system probably remained close to the liquidus while the crystal mush accumulated. This approach is analogous to that of Chai \& Naldrett (1992) for the Jinchuan Ultramafic Intrusion, in which a model of cumulus olivine in magma was proposed.

To examine which of the three Bushveld parental magmas is the most compatible with the mixing model, the sum of the squares of the deviations:

$$
[M(i)-C s(i)]^{2}
$$

[where $M(i)$ and $C s(i)$ are, respectively, the analyzed and calculated concentration of the $i^{\text {th }}$ element or oxide in the cumulate for each individual element] is minimized. $C s(i)$ is obtained by the equation:

$$
C s(i)=a(j) \cdot C p(j, i)+b \cdot C m(i)
$$

where $a(j)$ is the mass fraction of the $j^{\text {th }}$ mineral considered in the model, $b$ is the mass fraction of parental magma in the cumulate, $C p(j, i)$ is the concentration of the $i^{\text {th }}$ oxide in the $j^{\text {th }}$ mineral phase, and $C m(i)$ is the concentration of the $i^{\text {th }}$ oxide in the parental magma. Nine oxides, $\mathrm{SiO}_{2}, \mathrm{TiO}_{2}, \mathrm{Al}_{2} \mathrm{O}_{3}, \mathrm{FeO}$ (total), $\mathrm{MnO}, \mathrm{MgO}$, $\mathrm{CaO}, \mathrm{Na}_{2} \mathrm{O}$ and $\mathrm{K}_{2} \mathrm{O}$, were used in the calculations.

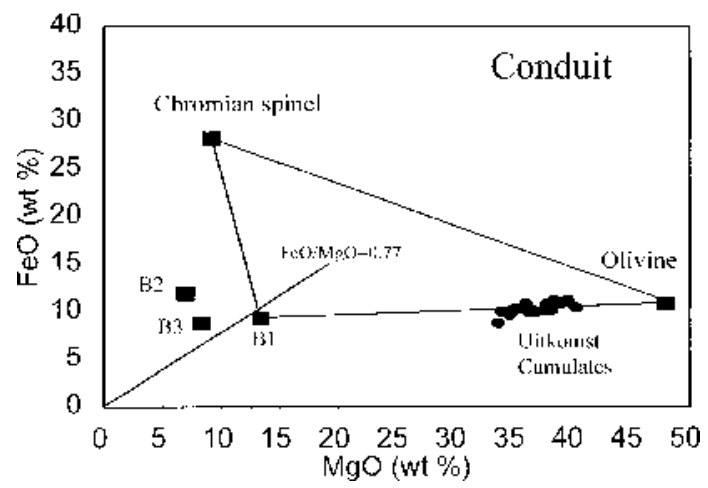

FIG. 5. Binary variation diagram of $\mathrm{MgO}$ versus $\mathrm{FeO}$ illustrating the end members of the mixing models (see text for explanation)
Since only two mineral phases are considered, the system has seven degrees of freedom and is therefore overdetermined. Accordingly, a least-squares minimization approach is justified.

The average compositions of B1, B2 and B3 (Table 3 ) were used alternatively in the calculations, as well as the average composition of chromian spinel over the relevant interval. For olivine, we took the three most primitive compositions of olivine from Gauert (1998) to minimize the effect of post-cumulus re-equilibration. The bold line through the origin in Figure 5 gives the $\mathrm{FeO}: \mathrm{MgO}$ ratio of a basaltic magma in equilibrium with olivine $\mathrm{Fo}_{88}$, which is the average Fo content of the olivine in the Main Harzburgite Unit.

To test which of the different magmas is most compatible with the model, $M(i)$ is plotted against $C s(i)$ for all the samples of cumulate rocks used in the calculation. If the choice of magma is correct, then the sample data will cluster on a line with a slope equal to one. An incorrect choice will show a bias away from the unitslope line.

TAELE 3. ESTMLAIE OF THE COMPOSITION OF T1E PARENTAL MAGMA FOR THE CEOSED-SYSTEM STAGE

\begin{tabular}{|c|c|c|c|c|c|c|}
\hline & D. 1 & $\mathrm{~B} 2$ & $\mathrm{B3}$ & $\begin{array}{l}\text { Culbaluted } \\
\text { :Wegma }\end{array}$ & Chromite & Olkitine \\
\hline $\mathrm{SiO}_{2} \mathrm{nt} \%$ & 55.77 & 49.92 & 50.79 & 53.60 & 0.00 & 4033 \\
\hline $\mathrm{TiO}_{2}$ & 0,33 & 0.68 & 0.39 & 112 & 1.65 & 0.00 \\
\hline $\mathrm{Al}_{2} \mathrm{O}_{3}$ & 11.34 & 16.21 & 1605 & 13.29 & 13.72 & 0.00 \\
\hline Feb latal & 9.32 & 11.95 & 890 & 9.79 & 28.23 & 10,94 \\
\hline MrO & 0.18 & 0.20 & 0,15 & 0.15 & $0.3-1$ & 0.15 \\
\hline $\mathrm{MgO}$ & 13.05 & 6.94 & 8.27 & 12.38 & 9.14 & 47.97 \\
\hline Calo & 6.38 & 1157 & 11.49 & 5.92 & - & 0.09 \\
\hline $\mathrm{Nat}-\mathrm{O}$ & 1.73 & 2. 15 & 2.32 & 232 & - & - \\
\hline $\mathrm{K}, \mathrm{O}$ & 0.85 & 0.15 & 0.20 & 0,85 & - & 001 \\
\hline $\mathrm{P}_{3} \mathrm{O}_{3}$ & o.m & 0.14 & $0,0,3$ & 0.09 & $=$ & - \\
\hline $\mathrm{Cr}_{2} \mathrm{O}_{3}$ & 9.16 & 0.03 & 0. 06 & 0.19 & 45.17 & - \\
\hline $\mathrm{NiO}$ & 0.05 & 001 & 0.52 & 0.06 & 0,11 & 0.37 \\
\hline total & 99.22 & 99.97 & 98.66 & 99,98 & 97.74 & 99.86 \\
\hline נדק & 71 & 95 & 69 & 47 & $=$ & - \\
\hline $\mathrm{Cu}$ & 50 & 85 & 26 & 63 & - & - \\
\hline $\mathrm{Ni}$ & 323 & 96 & 152 & 401 & - & - \\
\hline $\mathrm{Co}$ & 92 & 89 & 85 & 57 & . & - \\
\hline Ga & - & - & - & 9 & - & - \\
\hline Wh & - & - & - & 2 & - & - \\
\hline $\mathrm{sb}$ & - & - & - & 7 & - & - \\
\hline$Z r$ & 101 & 39 & 21 & 59 & . & - \\
\hline$Y$ & 15 & 21 & 13 & 10 & . & - \\
\hline $\mathrm{ST}_{\mathbf{T}}$ & 182 & 347 & 330 & 136 & - &. \\
\hline $\mathrm{Rb}$ & 33 & 2 & 3 & 20 & $=$ & - \\
\hline $\mathrm{U}$ & - & - & 2 & 4 & - & - \\
\hline Ih & - & - & $n$ & 3 & - & - \\
\hline $\mathrm{Pb}$ & 5 & 2 & 0 & 4 & - & - \\
\hline $\mathrm{Cr}$ & 1104 & 197 & 430 & 1.] 89 & - & - \\
\hline$v$ & 162 & 232 & 150 & 125 & - & - \\
\hline $\mathrm{Bg}$ & $=$ & 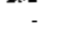 & - & 168 & . & - \\
\hline 56 & - & - & - & 14 & $=$ & - \\
\hline As & - & - & - & $\mathrm{I}$ & - & - \\
\hline
\end{tabular}
OF 'E'HE UITKOMST COMPLEX

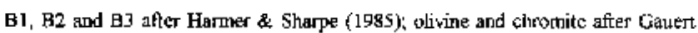
(1908), 


\section{RESUlts AND Discussion}

\section{Parental magma of the closed-system stage}

Application of Equation (2) above yielded a combined average composition for the interval between 750 down to 425 meters (Table 3, Figs. 6, 7) that is similar to Bushveld B1 magma. The calculations indicate that only the uppermost $20 \mathrm{~m}$ of the MHZB Unit should be considered part of the closed system, in contrast to the estimate of Gauert (1998) of 50 meters.

It is apparent from Figure 7 that with the exception of $\mathrm{Ti}$, all the major elements have concentrations closely comparable to those of the Bushveld B1 magma. The trace elements $\mathrm{Zn}, \mathrm{Co}, \mathrm{Zr}, \mathrm{Y}, \mathrm{Sr}$ and $\mathrm{Rb}$ show some deviation from the average $\mathrm{B} 1$ composition used. However, recent analytical work (E. Curl, pers. commun., 1999) on the B1 sills from the eastern Bushveld yielded concentrations for the relevant trace elements that are almost identical to those calculated here.

It also becomes apparent from this study that the silllike extensions mapped by Von Scheibler et al. (1995) probably did not play a significant role in the evolution of the Complex. It is conceivable that these sills formed isolated subsystems that did not participate significantly in the fractionation of the central body. The alternative is that these sills do not belong to the Uitkomst Complex at all.

Finally, it is evident from Figure 6 that the B2 and B3 magmas are unlikely candidates for the parental magma for the closed-system stage. Both B2 and B3 magmas have relatively low $\mathrm{SiO}_{2}$ values $(\sim 50 \%)$ combined with intermediate $\mathrm{Mg}$ values $(\sim 7 \% \mathrm{MgO})$ and high $\mathrm{Ca}$ values $(\sim 12 \% \mathrm{CaO})$. No realistic mixture of the cumulates in the closed-system stage could be made to satisfy these requirements.

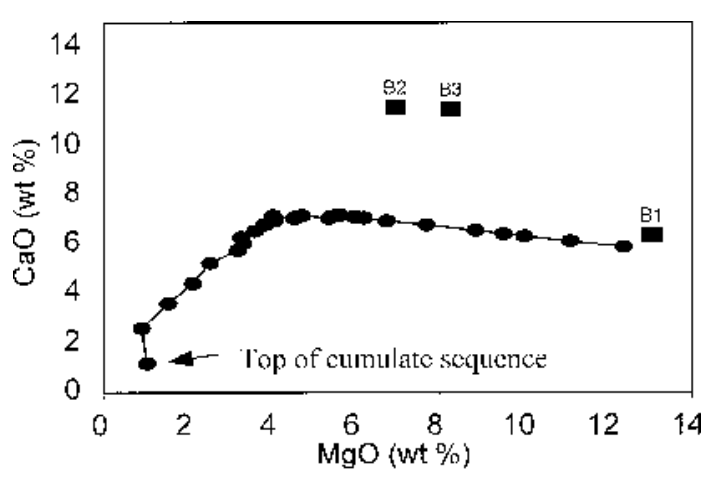

FIG. 6. Binary variation diagram illustrating the method by which the composition of the closed-system stage of the Complex has been determined. Starting with the low-MgO compositions at the top of the pile of cumulates, the cumulative data develop a trend that points at the B1 composition as the parental magma (see text for detail).

\section{Parental magma of the conduit stage}

The mixing calculations, using olivine, chromian spinel and, sequentially, Bushveld B1, B2 and B3 magmas as the third component, indicate that the B1 magma is the most probable candidate for the parental magma of the conduit stage. The oxide concentrations for each possible magma-type were calculated from the olivine, chromian spinel and magma compositions (Table 3), and the calculated mass-fractions (Table 4) were obtained by least-squares optimization for each magma type. As illustrated in Figure 8, the calculated $\mathrm{Al}$ and Ca concentrations compare well with those analyzed for $\mathrm{B} 1 \mathrm{magma}\left(\mathrm{SiO}_{2} \approx 55 \%\right.$ ), but less so for those analyzed for the $\mathrm{B} 2$ and $\mathrm{B} 3$ magmas $\left(\mathrm{SiO}_{2} \approx 50 \%\right)$. In a similar way, it can be shown that the calculated $\mathrm{SiO}_{2}$ values for the $\mathrm{B} 2$ and $\mathrm{B} 3$ magmas are consistently lower than the analyzed values, suggesting that the $\mathrm{B} 2$ and $\mathrm{B} 3$ magmas do not contain adequate $\mathrm{SiO}_{2}$ to satisfy the mixing models. These relationships are summarized in Table 4B, where it is shown that the average sum of squares of the deviations per sample for the B1 magma is about onethird of those for the B2 and B3 magmas.

Since the mixing models were calculated on the concentrations of major-element oxides, the corresponding trace-element concentrations provide an independent test of the overall model. In binary variation diagrams of the calculated fractions of B1 magma plotted against trace-element concentrations, the cumulates occupy fields consistent with olivine - chromian spinel - B1 magma mixtures (Fig. 9). This is particularly clear in the case of $\mathrm{Zr}, \mathrm{Rb}$ and $\mathrm{Sr}$ (Figs. 9a, b and c), but less so for $\mathrm{Y}$ and $\mathrm{V}$ (Figs. 9d, e), owing to the overlap in the relevant values for the B1, B2 and B3 magmas. The Zr, $\mathrm{Rb}, \mathrm{Sr}$ and $\mathrm{Y}$ contents of the olivine - chromian spinel mixtures in the cumulates have been assumed to be zero, whereas the $\mathrm{V}$ and $\mathrm{Ni}$ values were calculated from the

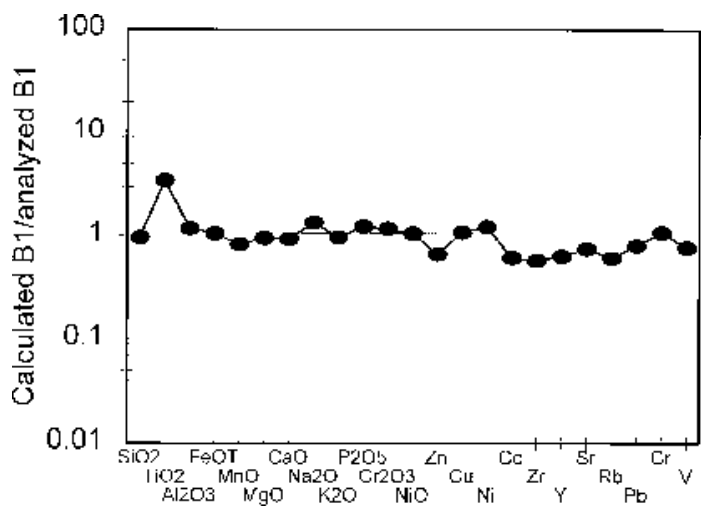

FIG. 7. Spidergram comparing the calculated B1 magma with the average B1 magma of Harmer \& Sharpe (1985). 
TABLE 4 RESULTS OF CALCEEATION OH

OLIYINE - CHROMIJE - BI WAGMA MIXING

\begin{tabular}{|c|c|c|c|c|}
\hline \multicolumn{5}{|c|}{ A. Calculated mass-ftactions } \\
\hline Sariple ID & Bl & Chưotnite & Olivites & Chr-Oy \\
\hline CP13 & 0,30 & 0.01 & 0.69 & 0.70 \\
\hline CP12 & 0.30 & 0.02 & 0.68 & 0.70 \\
\hline CP9 & 0.27 & 0,01 & 0.72 & 0.73 \\
\hline CPII & 0.28 & 001 & $0.7 \mathrm{l}$ & 072 \\
\hline CPM & 0,15 & 0.02 & 0.75 & 0.81 \\
\hline $\mathrm{MCl4}$ & 0,24 & 0.02 & 0.74 & 0.76 \\
\hline $\mathrm{MCl2}$ & 0.23 & 0.02 & 0.75 & 0.77 \\
\hline CP7 & 0,24 & 0.05 & 0.32 & 0.76 \\
\hline $\mathrm{MCB}$ & 0.31 & 0,07 & 0.66 & 0.69 \\
\hline HQA & 0.30 & 0,02 & 0.68 & 0.70 \\
\hline $\mathrm{HBA}$ & 0.30 & 0.07 & 0.67 & 0.70 \\
\hline YEC & 0.21 & 0.04 & 0.75 & 0.79 \\
\hline MCs & 0.20 & 004 & 0,76 & 0.80 \\
\hline $\mathrm{H} 5 \mathrm{~A}$ & 0.37 & 003 & 0,60 & 0.63 \\
\hline $115 \mathrm{~A}$ & 0.33 & 003 & 0,64 & 0.67 \\
\hline $\mathrm{H} 4 \mathrm{~A}$ & 0,38 & 0.00 & 0.62 & 0.62 \\
\hline $\mathrm{H} 2 \mathrm{~A}$ & 0,34 & 003 & 0.62 & 0.60 \\
\hline HCAB & 0,32 & 001 & 0.67 & 0.68 \\
\hline $\mathrm{H} 1 \mathrm{~A}$ & 0.47 & -003 & 0.59 & 0.57 \\
\hline $\mathrm{H} 18$ & 0.25 & 0.03 & 0.73 & 0.75 \\
\hline 0177 & 0.29 & .0 .01 & 0.72 & 0.71 \\
\hline$C^{\circ} 10$ & a.27 & 0.99 & 1.70 & 0.73 \\
\hline Averdge & 0.29 & 0.02 & $06 \%$ & 0.71 \\
\hline St. dew. & $0.0 \mathrm{~s}$ & 0.02 & 0.65 & 0.00 \\
\hline \multicolumn{5}{|c|}{ 7. A werage least sun of squares of the deviations'sample } \\
\hline B1 & 0.96 & & & \\
\hline $\mathrm{B} 2$ & 3.00 & & & \\
\hline $\mathrm{B} 3$ & 2.98 & & & \\
\hline
\end{tabular}

average proportions of these minerals in the cumulates (Table 4) and the compositions given by Gauert (1998).

Ni presents a special case in that the cumulates are obviously enriched in this element (Fig. 9f). The average $\mathrm{Ni}$ content of the olivine (Table 3 ) is $0.37 \% \mathrm{NiO}$, which is equivalent to $2908 \mathrm{ppm}$ Ni. Utilizing the equation of Hart \& Davies (1978), $\mathrm{D}_{(\mathrm{ol} / \mathrm{liquid} ; \mathrm{Ni})}=124 / \mathrm{MgO}-$ 0.9 , the $\mathrm{Ni}$ concentration in olivine in equilibrium with magma $\mathrm{B} 1(13.36 \mathrm{MgO}, 328 \mathrm{ppm} \mathrm{Ni})$ is inferred to be $2750 \mathrm{ppm}$. On a MgO-Ni diagram (Fig.10), the cumulates plot outside the triangle olivine - chromian spinel - B1 magma. If the small amount of chromian spinel $( \pm 2 \%$; Table 4$)$ is ignored, a line from B1 through the cumulates should project to the Ni content of olivine at $47.97 \% \mathrm{MgO}$. On the basis of a least-squares-regression analysis (line AA, Fig. 10), this composition corresponds to a value of $3568 \mathrm{ppm} \mathrm{Ni}$, which appears significantly higher than the value of $2908 \mathrm{ppm} \mathrm{Ni}$ in olivine determined by analysis.

In our opinion, this discrepancy in Ni concentration is best explained by minor amounts of sulfide in the cumulates. This notion is corroborated by the data on sulfur content. The whole rocks contain between 0.03 and $0.12 \% \mathrm{~S}$, which is regarded as too high to be attributed to the trapped melt alone. Typical basaltic magmas contain about $0.1 \% \mathrm{~S}$ and, since the B1 fraction in the cumulates amounts to about $0.3, \mathrm{~S}$ in the cumulates at- tributable to trapped melt should not be more than approximately $0.03 \%$. These findings are important because they suggest that magma B1 that flowed through the conduit was saturated in sulfur and precipitated small quantities of sulfide together with chromian spinel and olivine.

\section{Emplacement of the Uitkomst Complex}

In addition to the large chemical difference between the Basal Gabbro Unit and the Lower Harzburgite Unit, the former is known to be relatively free of xenoliths. However, a transitional mineralogical-chemical relationship is clearly in evidence. Also, we have shown here that the harzburgitic and higher units in the succession have a B1-type magma as parent, whereas De Waal $\&$ Armstrong (2000) recently proposed that the Basal Gabbro Unit is derived from a mildly alkaline tholeiitic (Bu-type) magma. The question is how to bring all this information together in a meaningful way. We believe that the answer is to be found in the mechanism of emplacement and timing of the magma injections.

It is proposed here that the tubular morphology of the Uitkomst Complex resulted when a near-horizontal fault (bedding plane fault) intersected and was offset by an existing northwest-trending vertical fracture zone (Fig. 11a). Such vertical fracture zones are common in the surrounding country-rock in that area (De Waal \& Gauert 1997). Horizontal shearing and faulting may have derived from tensional conditions resulting from uplift due to increased heat flow during the onset of the emplacement of the Bushveld Complex. In the process, a long tubular opening was created, which filled with Bu magma as it opened (Fig. 11b), and so stabilized the chamber walls and roof. Conceptually, the very first $\mathrm{Bu}$ magma may also have come in as a sill, as indeed observed in some profiles (Fig. 3). The Bu magma started to crystallize to form the Basal Gabbro Unit. After about 6 meter of gabbro had formed, the Bu magma was replaced by the first batch of xenolith-bearing B1 magma. This event introduced the conduit stage of solidification (Fig. 2). The B1 magma, containing olivine, chromian spinel and minor sulfide in suspension, moved through the tubular conduit, and the suspended load was apparently concentrated in the magma by flow segregation. Several flows of this nature are in evidence (detail beyond the scope of this paper), with later flows less contaminated by xenoliths. Finally, when bottom-up solidification reached a level about 425 meters above the base of the intrusion, the rate of magma flow diminished, giving rise to the closed-system stage. Fractional crystallization yielded the upper part of Main Harzburgite unit as well as the Pyroxenite and Gabbronorite units. Scouring action during the conduit stage by the flowing magma caused erosion of the sidewalls of the chamber; some lateral intrusion might have taken place as well (Fig. 11c). 

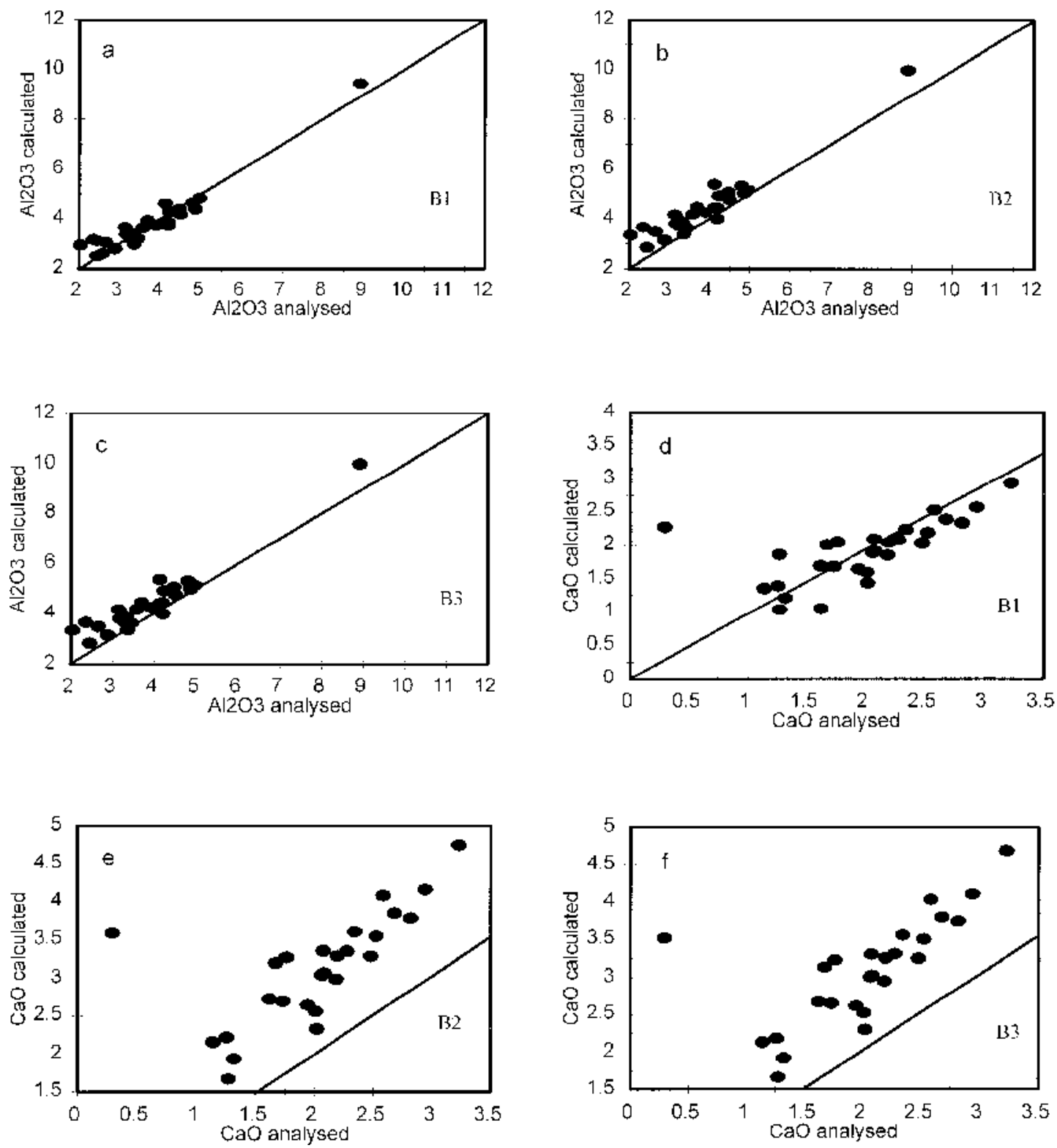

FIG. 8. Variation diagrams for $\mathrm{Al}_{2} \mathrm{O}_{3}$ and $\mathrm{CaO}$ (determined by analysis versus calculated) for ternary mixing models using $\mathrm{B} 1$ ( $a$ and d), B2 (b and e), and B3 magma (c and f) in the ternary mixtures. The least bias is obtained with the B1 magma, indicating its parental status.

Three lines of evidence support the scenario given above. First, a vertical northwest-trending fracture zone is indeed observed in the field along the lower southwestern contact of the Complex. Furthermore, this fracture zone contains numerous veins of fibrous quartz that strike roughly parallel to the trend of fracture zone it- self, and they appear to be superimposed on the earlier fracture planes. The quartz fibers in these veins are oriented in a north-south direction throughout, suggesting a tensional episode with an axis of minimum stress in this direction. We contend that the formation of the fibrous quartz postdates the vertical fracture zone and is 

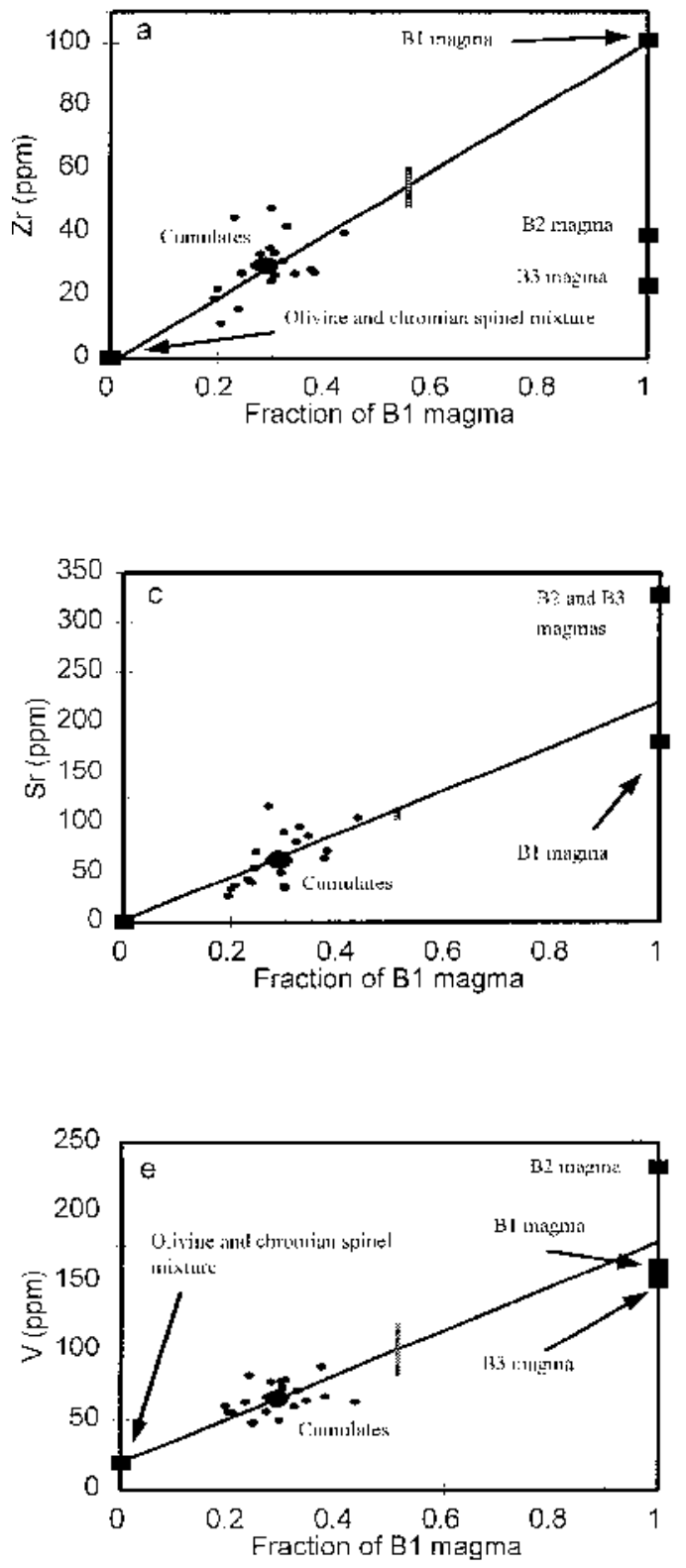
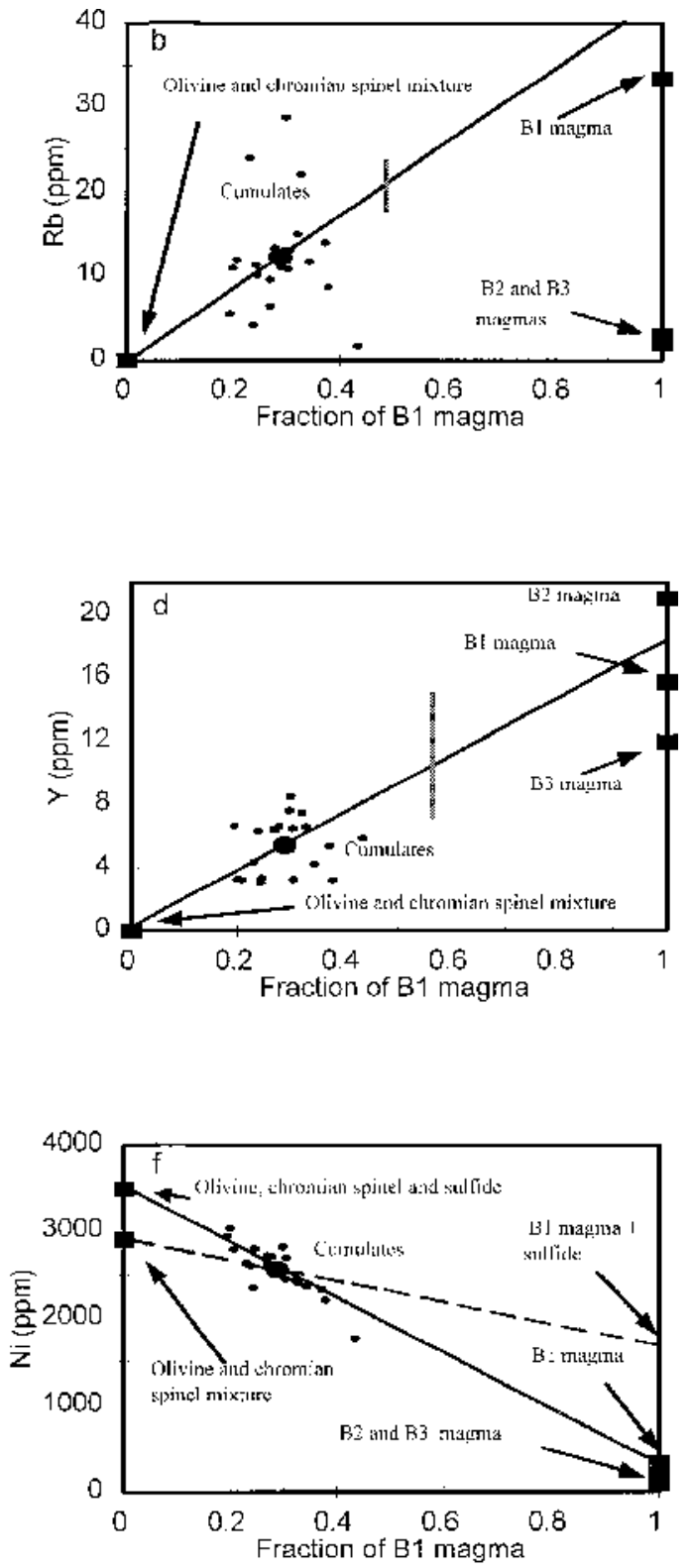

FIG. 9. Diagrams depicting the concentrations of trace elements against the fraction of B1 magma in the cumulates of the conduit stage. Solid line projects from cumulus minerals, through cumulates (whole rock), to the composition of the magma. Plots for $\mathrm{Zr}$, Rb and $\mathrm{Sr}$ (a, b, c) confirm B1 as a parental magma to the conduit stage cumulates. V and Y (d, e) are less conclusive. $\mathrm{Ni}$ (f) suggests the presence of trace amounts of sulfide in addition to olivine, chromian spinel and B1 magma (see text). Vertical bars in each case give two standard errors of the analytical technique. For Ni, this bar is reduced to a point.

coeval with the emplacement of the Uitkomst Complex, and that it relates to the dilational opening, by oblique shear, into which the Bu magma was emplaced.
The second line of evidence comes from the existence of the Marginal Gabbro (De Waal \& Gauert 1997). The latter rock has a composition comparable to that of 


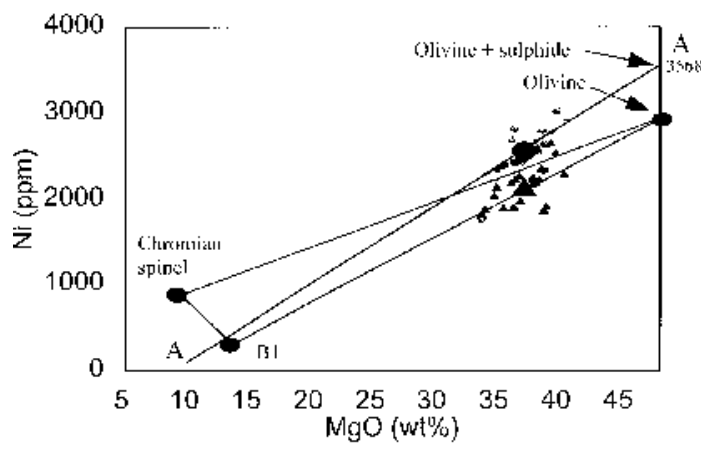

FIG. 10. Ni-MgO plot illustrates the quantity of $\mathrm{Ni}$ ascribed to sulfide. The cumulates (small ellipses) define a line (AA) that projects from the $\mathrm{B} 1$ composition to a Ni value of 3568 $\mathrm{ppm}$ at $47.97 \% \mathrm{MgO}$. This deviation from the expected $\mathrm{Ni}$ content of the olivine is due to minor sulfide mixed in with the cumulates. Corrected for this sulfide, the cumulates occupy a space between B1 magma and olivine (triangles). The large ellipse and triangle mark the average of the uncorrected and sulfide-corrected cumulates, respectively (see text for detail).

the Basal Gabbro Unit and forms a contact zone between the Lower, Chromitiferous and Main Harzburgite zones and the country rock on the farm Uitkomst. The presence of this rock up to about 200 meters above the base of the intrusion is taken as evidence that the chamber was probably filled with gabbroic magma before the formation of the layered sequence.

Finally, the proposed model is in agreement with the observed patterns of element distribution of the Complex, as given by Gauert et al (1995). Here we use a $\mathrm{Zr}$ diagram (Fig. 12) for illustrative purposes. Near the base of the Complex, high but variable concentrations of $\mathrm{Zr}$ mark the Basal Gabbro Unit (Fig. 12). However, the Lower, Chromitiferous and Main Harzburgite units show little variation, confirming the conduit nature (continuous replenishment of magma) in this sequence. The variance observed in these rocks is well explained by minor variations in the trapped liquid content. $\mathrm{Zr}$, being almost completely incompatible in crystallizing basic magmas, is accommodated in the trapped liquid of the cumulate rocks. Using the data from Table 4, and starting with $100 \mathrm{ppm} \mathrm{Zr}$ in the magma, it follows that the cumulates must contain between 20 and $45 \mathrm{ppm} \mathrm{Zr}$ (Fig. 12). When the closed-system stage developed, fractionation started. In the lower 20 meters of harzburgitic rocks, the fraction of melt remaining is relatively high, and the data do not allow any inferences to be made. However, in the Pyroxenite Unit, the $\mathrm{Zr}$ concentrations drop off, largely because of the generally low quantities of trapped magma in the almost monomineralic orthopyroxenites. Above the pyroxenite, $\mathrm{Zr}$ rapidly increases with increasing fractionation. A tenta-
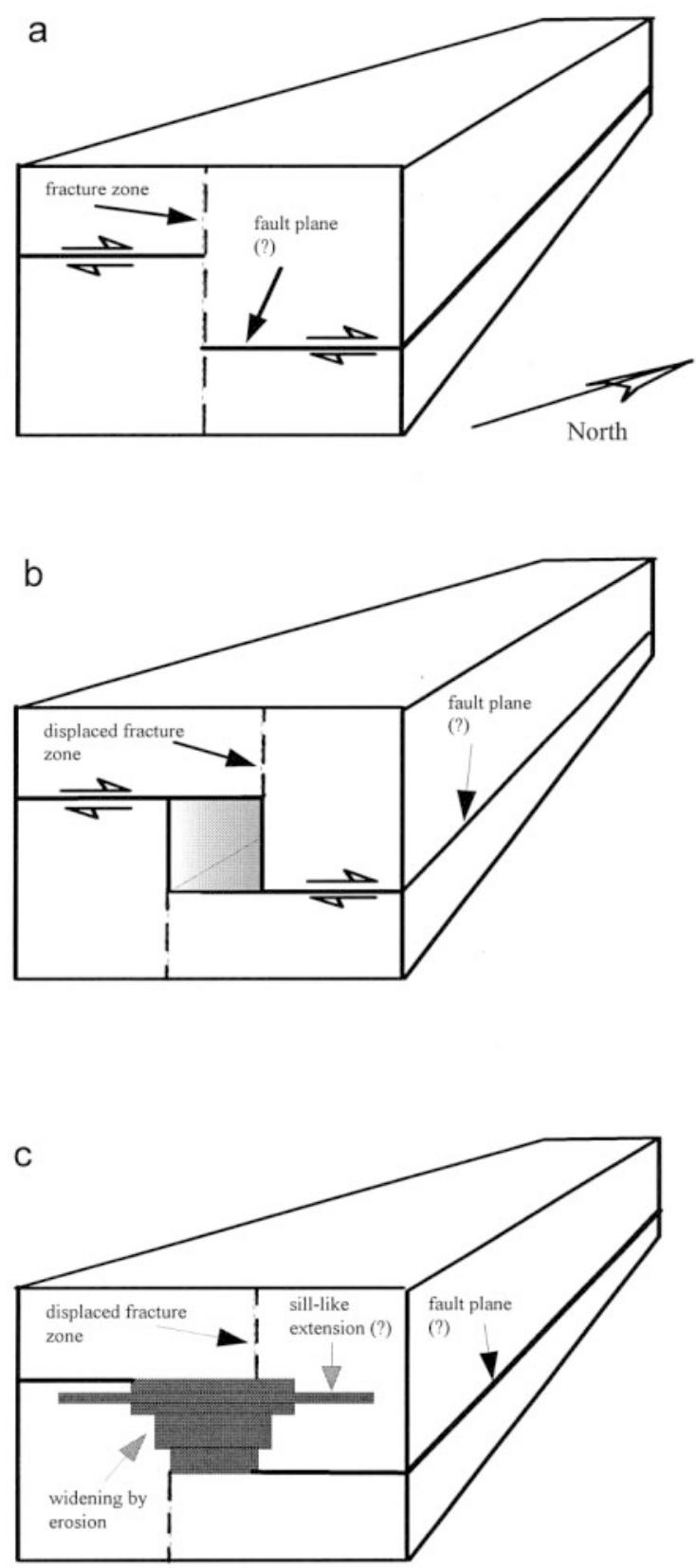

FIG. 11. Proposed mechanism of space creation during emplacement of the Uitkomst Complex. A horizontal fault plane (bedding plane fault) intercepts and is offset by an existing vertical fracture zone (a) to create a northweststriking tubular opening (b) that filled with Bu magma. B1 magma replaced the Bu magma after small fraction of the latter crystallized to create the conduit stage of solidification. At the 425-meter level, the flow of magma stopped, giving rise to the closed-system stage. Erosion of the sidewalls during the conduit stage is envisaged (see text for detail). 


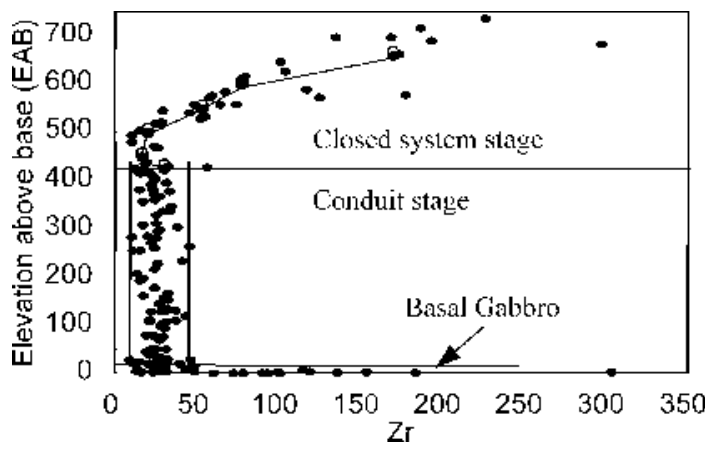

FIG. 12. Zr variation in the Uitkomst Complex as a function of elevation above the base in meters. Two vertical lines in the conduit stage represent the calculated concentrations of $\mathrm{Zr}$ in the cumulates. In the closed system, the solid line connecting partly filled circles represents a calculated model based on fractional crystallization (see text for detail).

tive fractionation model $\left(\mathrm{Zr}_{\text {magma }}=100 \mathrm{ppm} ; 15 \%\right.$ trapped liquid in pyroxenite and 30\% in harzburgite and plagioclase cumulates; $\mathrm{Zr}$ perfectly incompatible) is shown in Figure 12, with a line connecting different stages of fractionation (partly filled open circles).

\section{Sulfide mineralization and exploration}

The possible triggering mechanisms for precipitation of the economically important sulfide in the Uitkomst Complex call for some comment. A number of chemical and physical factors seem to have contributed to the formation of the sulfide in the Basal Gabbro, Lower and Chromitiferous Harzburgite units. First, the large chemical difference between the mildly alkaline gabbroic $\mathrm{Bu}$ magma (responsible for the Basal Gabbro Unit: De Waal \& Armstrong 2000) and the boninitic B1 magma (here shown to be parental to the harzburgitic units) is notable. Mixing of these magmas would favor sulfide precipitation on the level of the interface between the Basal Gabbro and Lower Harzburgite units. Secondly, the presence of dolostone xenoliths in the Lower Harzburgite indicates oxidative conditions that would contribute to early sulfide saturation of the magma. Thirdly, Gauert et al. (1996), using S isotopes, provided evidence that about $10 \%$ of the sulfur in the sulfide was derived from the country rock (dolomite). Finally, the flow of magma through the tubular conduit lends itself to mixing of the different chemical subsystems as well as shear agglomeration of sulfide droplets, enhancing saturation and segregation of sulfide, respectively. These factors all provide clear guidelines in the exploration for similar deposits along the footwall contact of the Rustenburg Layered Suite of the Bushveld Complex.

\section{Conclusions}

The data presented in this paper support the following conclusions.

1. The Uitkomst Complex (concordant zircon SHRIMP age: $2044 \pm 8 \mathrm{Ma}$ ) seems to be coeval with the Rustenburg Layered Suite of the Bushveld Complex.

2. The Lower, Chromitiferous and Main Harzburgite units (excluding the upper 20 meters of the latter unit) formed during the conduit stage of the Complex from a magma compositionally similar to the Bushveld B1 magma that flowed through the conduit.

3. During the conduit stage, suspended crystals of olivine, chromian spinel and small amounts of sulfide concentrated in the B1 magma largely owing to flow segregation, giving rise to cumulates with an average of $30 \%$ trapped liquid.

4. The upper 20 meters of the Main Harzburgite Unit as well as the Pyroxenite and Gabbronorite units crystallized under closed-system conditions from a magma compositionally similar to the Bushveld B1 magma.

5. The tubular shape of the Uitkomst Complex probably resulted when a horizontal fault (bedding plane fault) intersected and was offset by a vertical fracture zone under tensional conditions.

The model proposed in this study provides a sound basis from which to do further studies on the origin of the massive and disseminated sulfide mineralization found in the Uitkomst Complex. Economic concentrations of sulfide in the Rustenburg Layered Suite, with which the Uitkomst Complex shares parental magmas, are notoriously absent. We propose that the presence of the Bu-type magma is a major factor in the formation of sulfide in the Uitkomst Complex; research in this direction is in progress.

\section{ACKNOWLEDGEMENTS}

The authors thank Sarah-Jane Barnes and Robert Thériault for their constructive criticism on an earlier version of the paper. Facilities, financing and material support from the University of Pretoria, the National Research Foundation, as well as the Anglo-American Prospecting Services are gratefully acknowledged. We also thank Maggi Loubser for XRF analyses, and AVMIN Ltd., through Dr. Hennie Theart, for providing the sample for SHRIMP analysis.

\section{REFERENCES}

ANON. (1997): Nkomati - South Africa's first primary nickel mine. South African Mining Coal, Gold and Base Minerals, July, 27-31.

BÉDARD, J.H. (1994): A procedure for calculating the equilibrium distribution of trace elements among the minerals of cumulate rocks, and the concentration of trace elements in coexisting liquids. Chem. Geol. 118, 143-153. 
CHAI, GANG \& NALDRETT, A.J. (1992): The Jinchuan ultramafic intrusion: cumulate of a high-Mg basaltic magma. J. Petrol. 33, 277-303.

Davies, G. \& Tredoux, M. (1985): The platinum-group element and gold contents of the marginal rocks and sills of the Bushveld Complex. Econ. Geol. 80, 838-848.

DE WaAl, S.A. \& Armstrong, R.A. (2000): The age of the Marble Hall diorite, its relationship to the Uitkomst Complex, and evidence for a new magma type associated with the Bushveld Complex. S. Afr. J. Geol. 103, 128-140.

\& GaUerT, C.D.K. (1997): The Basal Gabbro Unit and the identity of the parental magma of the Uitkomst Complex, Badplaas, South Africa. S. Afr. J. Geol. 100, 349361.

FRANCIS, D. (1994): Chemical interaction between picritic magmas and upper crust along margins of the Muskox Intrusion, Northwest Territories. Geol. Surv. Can., Pap. 9212.

Gauert, C.D.K. (1998): The Petrogenesis of the Uitkomst Complex, Mpumalanga Province, South Africa. Ph.D thesis, Univ. Pretoria, Pretoria, South Africa.

, DE WAal, S.A. \& Wallmach, T. (1995): Geology of the ultrabasic to basic Uitkomst Complex, eastern Transvaal, South Africa: an overview. J. Afr. Earth Sci. 21, 553570 .

JoRdaAn, L.D., DE WaAL, S.A. \& WaLlmach, T. (1996): Isotopic constraints on the source of the sulphur for the base metal sulfides of the Uitkomst Complex, Badplaas, South Africa. S. Afr. J. Geol. 99, 41-50.

HARMER, R.E. \& SHARPE, M.R. (1985): Field relations and strontium isotope systematics of the marginal rocks of the eastern Bushveld Complex. Econ. Geol. 80, 813-837.

HART, S.R. \& DAviEs, K.E. (1978): Nickel partitioning between olivine and silicate melt. Earth Plan. Sci. Lett. 40, 203-219.

Hatton, C.J. \& ShaRPe, M.R. (1989): Significance and origin of boninite-like rocks associated with the Bushveld Complex. In Boninites (A.J. Crawford, ed.). Unwin Hyman, London, U.K.

Kenyon, A.K., Attridge, R.L. \& Coetzee, G.L. (1986): The Uitkomst nickel-copper-deposit, eastern Transvaal. In Mineral Deposits of Southern Africa (C.R. Anhauesser \& S. Maske, eds.). The Geological Society of South Africa, Pretoria, South Africa (1009-1017).

LAmberT, D.D. \& Simmons, E.C. (1987): Magma evolution in the Stillwater Complex, Montana. I. Rare earth element evidence for the formation of the ultramafic series. Am. J. Sci. 287, 1-32.
Li, Chusi, Lightfoot, P.C., Amelin, Y. \& Naldrett, A.J. (2000): Contrasting petrological and geochemical relationships in the Voisey's Bay and Mushau Intrusions, Labrador, Canada: implications for ore genesis. Econ. Geol. 95, 771-799.

Loferski, P.J., Arculus, R.J. \& Czamanske, G.K. (1994): Rare earth element evidence for the petrogenesis of the banded series of the Stillwater Complex, Montana, and its anorthosites. J. Petrol. 35, 1623-1649.

MAthEZ, E.A. (1995): Magmatic metasomatism and formation of Merensky reef, Bushveld Complex. Contrib. Mineral. Petrol. 119, 277-286.

Morse, S.A. (1969): The Kiglapait Layered intrusion, Labrador. Geol. Soc. Am., Mem. 112.

Norrish, K. \& HutTon, J.T. (1969): An accurate X-ray spectrographic method for the analysis of a wide range of geological samples. Geochim. Cosmochim. Acta 33, 431-453.

RAEDECKe, L.D. (1982): Petrogenesis of the Stillwater Complex. Ph.D. thesis, Univ. of Washington, Seattle, Washington.

Roeder, P.L. \& EMSLIE, R.F. (1970): Olivine-liquid equilibrium. Contrib. Mineral. Petrol. 29, 275-289.

Sharpe, M.R. (1981): The chronology of magma influxes to the eastern compartment of the Bushveld Complex as exemplified by its marginal border groups. J. Geol. Soc. London 138, 307-326.

(1985): Strontium isotope evidence for preserved density stratification in the main zone of the Bushveld Complex, South Africa. Nature 316, 119-126.

Strauss, T.A.L. (1995): The Petrology and Geochemistry of the Basal Gabbro Unit, Uitkomst Complex. M.Sc. thesis, Rhodes Univ., Grahamstown, South Africa.

VAN ZYL, A.M. (1996): The Sulfides of the Uitkomst Complex, Badplaas, South Africa. M.Sc. dissertation, Univ. of Pretoria, Pretoria, South Africa.

Von Scheibler, W.H.T.M., Cawthorn, R.G., Kenyon, A.K. \& Allen, I.V.M. (1995): Ni-Cu sulfide mineralization in the Uitkomst intrusion. Geol. Soc. S. Afr., Centennial Geocongress '95, Ext. Abstr. 1, 133-136.

Wagner, P.A. (1929): The Platinum Deposits and Mines of South Africa. Oliver and Boyd, Edinburgh, U.K.

Received December 15, 1999, revised manuscript accepted October 6, 2000. 